\title{
SEA SURFACE TEMPERATURE AND ITS VARIABILITY IN THE INDONESIAN REGION
}

BY TANGDONG QU, YAN DU, JANE STRACHAN, GARY MEYERS, AND JULIA SLINGO

Lying at the confluence of the Eurasian Plate, the Indo-Australian Plate, and the Pacific Plate is the Indonesian archipelago. It is composed of more than 3,000 islands, covering a global surface area equivalent to the continental United States and with a cumulative coastal perimeter that is more than twice Earth's circumference. The mechanisms that generate and maintain sea surface temperature (SST) (Figure 1a) within the Indonesian seas are a consequence of the complex topography and connectivity between the Pacific and Indian Oceans. In addition to surface heat fluxes, intense tidal mixing of surface and thermocline waters and variability in thermocline depth driven remotely by winds over the Pacific and Indian Oceans play a role in generating and maintaining SST. Con- sequently, regional ocean dynamics and SST are important factors in regional climate, with important consequences for global climate.

The Indonesian region, also known as the "Maritime Continent," has been identified as an area of major climatic importance both locally and globally. The region, along with equatorial Africa and South America, is recognized as a primary energy source for the entire global circulation system. The main supply of energy is latent heating, released from the condensation of water vapor when clouds and precipitation form due to cumulus convection. Convective activity, which dominates weather in the tropics, is variable on a range of spatial and temporal scales, making the climate of the Maritime Continent and its re- lationship to SST fascinating to study. The SSTs across the Indonesian region are of paramount importance to convection and, hence, precipitation distribution (Figure 1b). Warm SSTs around the islands of the Maritime Continent lead to vast amounts of evaporation triggering surface heat flux, which drive the deep convective cell over the region. The relationship between SST and convective activity is highly sensitive; modeling studies (Miller et al., 1992) and observations (McBride et al., 2003) show that small changes in the SST within the Maritime Continent can result in significant changes in precipitation patterns across the Indo-Pacific region (Ashok et al., 2001; Neale and Slingo, 2003). The effect of these changes on the economy and environment of the region is widespread. 

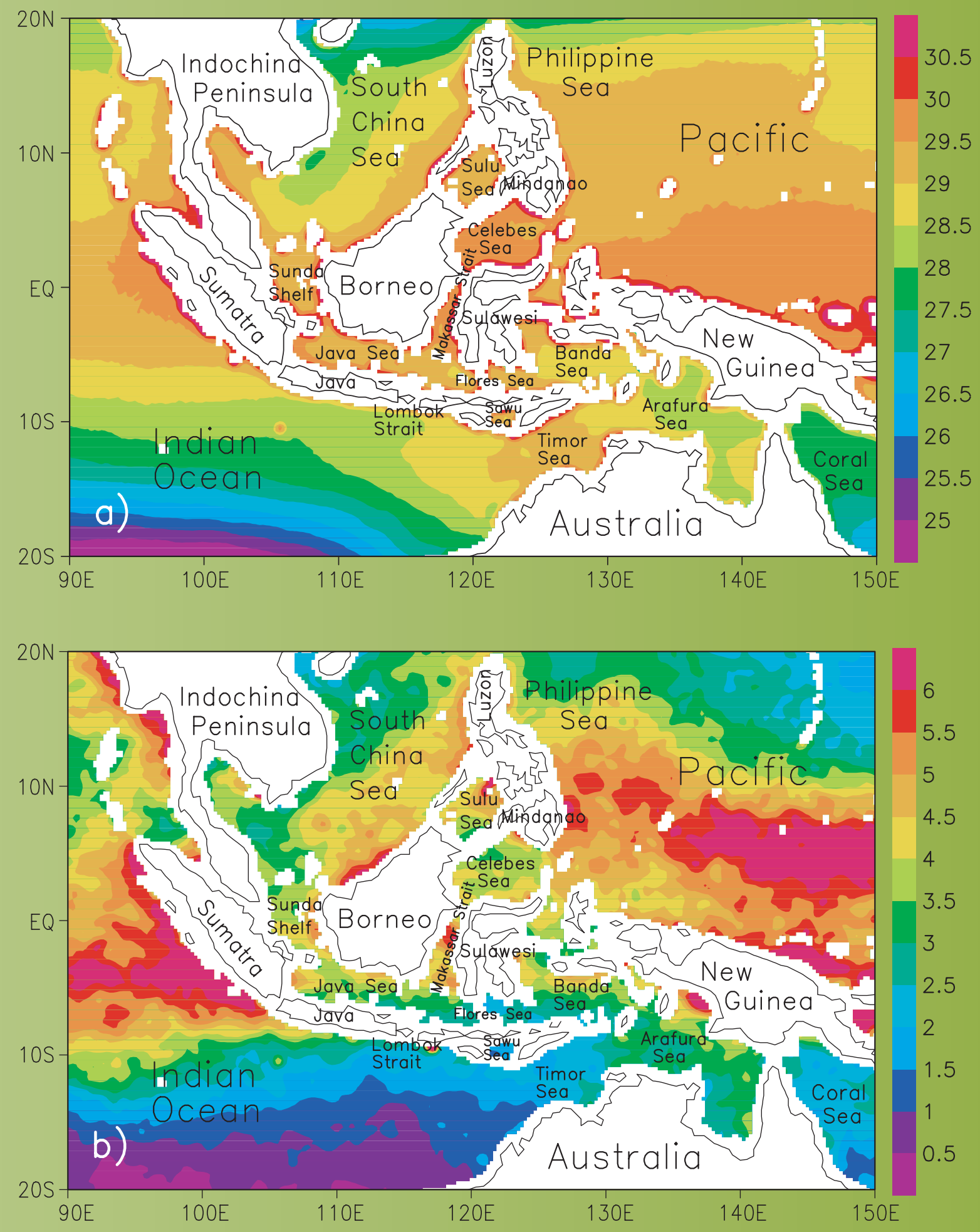

Figure 1. Tropical Rainfall Measuring Mission's (TRMM) (Kummerow et al., 1998) (a) sea surface temperature $\left({ }^{\circ} \mathrm{C}\right.$ ) and (b) precipitation $\left(10^{3} \mathrm{~mm} / \mathrm{yr}\right.$ ) averaged from December 1997 to December 2003. Warm sea surface temperature in the region leads to strong convection and significant precipitation. 
The Maritime Continent, with its huge range of variability in atmospheric and oceanic activity, is a major modeling challenge. Many sophisticated atmospheric General Circulation Models (GCMs) do not agree with observations. With improving data on regional providing a new view of SST fields and other ocean-atmosphere variables in the Indonesian region at unprecedented resolutions in both time and space. This paper provides a brief overview of the recent studies that have identified processes controlling SST variability and

\section{The Indonesian region SST is of major}

importance to atmospheric state, not only

over the region itself, but globally. Convection, which is dependent on the SST, is the dominant atmospheric process over the region.

precipitation, and model validation, we recognize that rainfall is systematically underestimated. Neale and Slingo (2003) argue that the deficient rainfall over the Maritime Continent could be responsible for systematic errors elsewhere, both in the tropics and extratropics. The discrepancy in rainfall suggests inadequate representation of the physical system. Having a good understanding of observed SST variability as it relates to regional ocean dynamics is key to improved model simulations.

SST variability is also an important influence on Indonesia's marine ecological systems, which harbor more than 20 percent of the world's species of plants and animals. The inhabitants of the region, or at least a significant part of them, depend on these marine resources for food, and many for their livelihood. The rapid advance in space-based microwave remote sensing is revolutionizing ocean observations, in particular related interactions with the atmosphere. We begin with a description of general characteristics of SST variability, present data on the sensitivity of the atmosphere to underlying SST, and then continue with a survey of local and remote oceanic mechanisms that affect SST. Finally, we discuss the issues that need to be addressed by further research.

\section{GENERAL CHARACTERISTICS OF SST VARIABILITY}

SST variability in the region is generally small compared with that in the tropical eastern Pacific due to the lack of strong equatorial upwelling. However, as with the surrounding western Pacific and eastern Indian Ocean warm pools, the mean SST is high (Figure 1a), and relatively small variations play an important role in coupled ocean-atmosphere processes. The largest seasonal SST cycle occurs in the Timor, Arafura, Banda, and the South China Seas, where the SST peak-to-peak amplitude exceeds $4^{\circ} \mathrm{C}$ (Figure 2a). The amplitude is much larger than in the surrounding heat pools in both the western Pacific and eastern Indian Ocean, where the amplitude is less than $1.5^{\circ} \mathrm{C}$. On the interannual time scale (Figure 2b), the highest SST variability $\left(>4.0^{\circ} \mathrm{C}\right)$ occurs along and offshore the Java and Sumatra coasts, indicative of a strong remote influence of the equatorial Indian Ocean combined with local upwelling (discussed later). The interannual variability in the Timor, Arafura, and Banda Seas is smaller (less than $2.0^{\circ} \mathrm{C}$ ).

\section{INFLUENCE OF THE MONSOON ON SST}

The Asian monsoon has a dominant influence on SST variation. In August, when the southeast monsoon prevails (Figure $3 \mathrm{a}$ ), a broad area south of $5^{\circ} \mathrm{S}$ cools, with the temperature minima in the upwelling zone south of Java and over the Arafura Shelf. The cool waters appear to be carried into the eastern Java

Tangdong Qu (tangdong@hawaii.edu) is Associate Researcher, International Pacific Research Center, School of Ocean and Earth Science and Technology, University of $\mathrm{Ha}$ waii, Honolulu, HI, USA. Yan Du is Postdoctoral Fellow, International Pacific Research Center, School of Ocean and Earth Science and Technology, University of Hawaii, Honolulu, HI, USA. Jane Strachan is Ph.D. student, NCAS-Centre for Global Atmospheric Modelling, University of Reading, UK. Gary Meyers is Senior Principal Research Scientist, CSIRO Marine Research, Hobart, Tasmania, Australia. Julia Slingo is Director, NCAS-Centre for Global Atmospheric Modelling, University of Reading, UK. 
Sea, then flow northwestward and enter the South China Sea through Karimata Strait. To compensate the outflow in the surface layer, relatively cold water is draw from below, which apparently contributes to the cooling in the southern Java and Flores Seas (Wyrtki, 1961). In the Makassar Strait, where Coriolis parameter is close to zero, surface water flows northward, primarily in the direction of the wind. The effect of the surface flow is reduced by the enhanced subsurface flow from the Pacific (Susanto and Gordon, 2005), and as a result, the SST in the Makassar Strait is still higher than $29^{\circ} \mathrm{C}$ during this season.

The monsoon wind reversal drives the surface layer of the Java Sea southeastward (Figure $3 \mathrm{~b}$ ), bringing relatively cool, fresh South China Sea water into the region (Wyrtki, 1961). Within the internal Indonesian seas, the SST is lowest in the western Java Sea, while the enhanced surface heat flux makes SST higher than $28^{\circ} \mathrm{C}$ in the rest of the archipelago. The South Java Current (Quadfasel and Cresswell, 1992; Bray et al., 1996) warms the area south of Java in this season, as discussed in more detail later.

\section{SENSITIVITY OF THE}

\section{ATMOSPHERE TO UNDERLYING}

\section{SST}

The Tropical Rainfall Measuring Mission (TRMM) Microwave Imager (TMI) has provided a description of the SST patterns in Indonesia in much greater spatial detail than ever before. The coarse resolution used by global models poorly represents the geographical detail of the Maritime Continent. At low resolution, the high SSTs in the shallow coastal regions are lost. This detail is crucial to the accurate forcing of convective processes, particularly on the diurnal time scale. The complex system of islands, narrow peninsulas, and shallow seas give rise to extensive land-sea breeze circulations and gravity wave effects (Yang and Slingo, 2001) that can influence the energy and moisture budgets and hence the mean climate of the region (Neale and Slingo, 2003). The land-sea surface temperature contrasts, along with the coastal and orographical detail, are crucial for this complex diurnal cycle, one of the most important modes of convective variability in the region. However, global atmospheric models currently misrepresent the diurnal cycle over the islands in both phase and amplitude. This shortfall
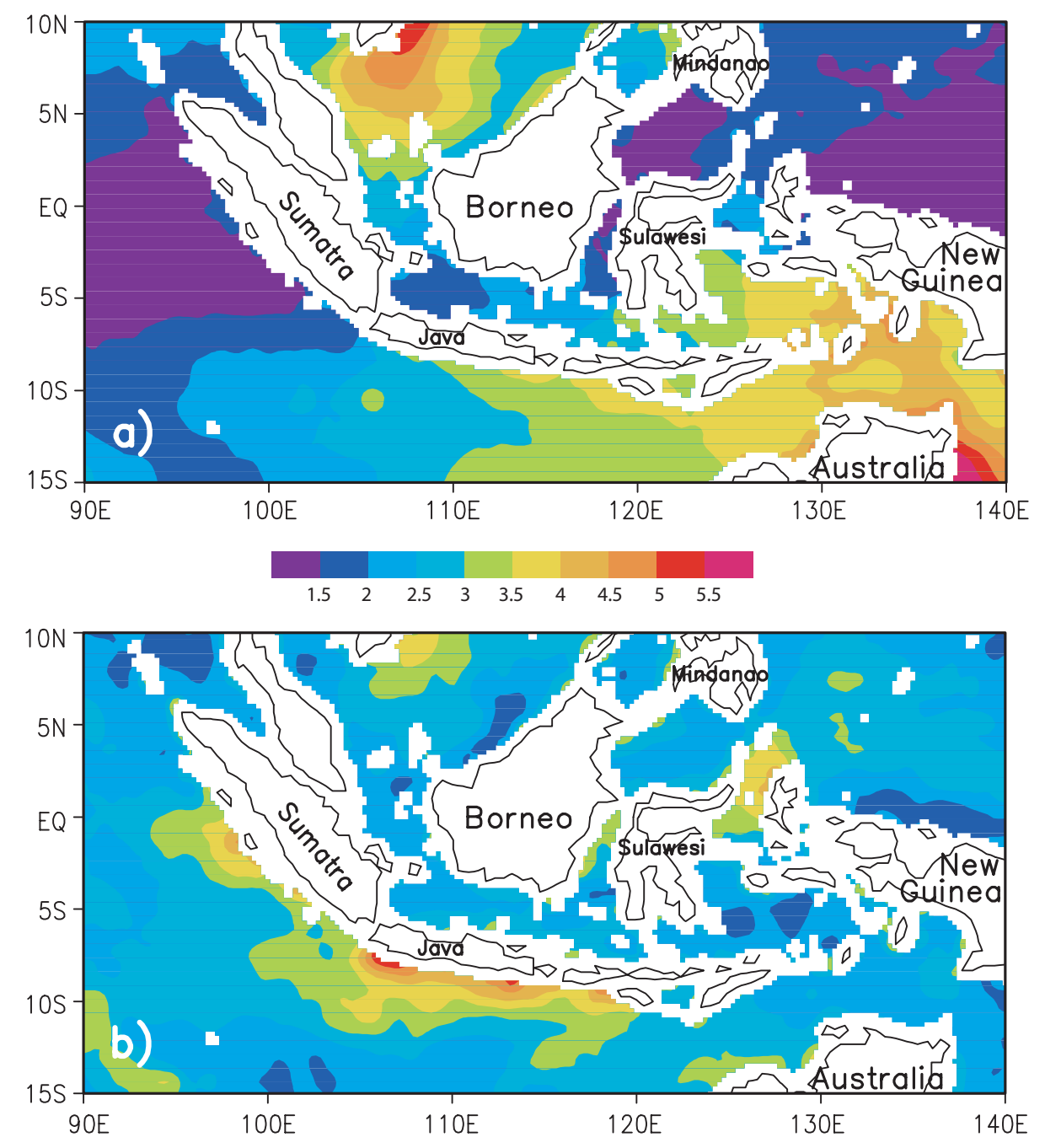

Figure 2. Peak-to-peak amplitude of (a) seasonal and (b) interannual variability in TRMM sea surface temperature $\left({ }^{\circ} \mathrm{C}\right)$ from December 1997 to June 2004 . The largest seasonal cycle $\left(>4.0^{\circ} \mathrm{C}\right)$ occurs in the Timor, Arafura, Banda, and South China Seas. The largest interannual variability $\left(>4.0^{\circ} \mathrm{C}\right.$ ) occurs along and offshore the Java and Sumatra coasts. 
may be due to a combination of inaccuracies in the geographical representation, prescribed SSTs, and parameterization of convective processes.

Climate-model experiments that show the sensitivity of the atmosphere to Indonesian SST are just beginning to emerge (Figure 4a). A careful comparison (not presented) of TMI-SST to the often-used coarse-grid AMIP2-SST (AMIP2 [Atmospheric Model Inter- comparison Project, second phase] is a standard experimental protocol for global atmospheric GCMs) (Gates, 1992) shows systematic differences throughout the region as large as $1^{\circ} \mathrm{C}$. Experiments run on the atmosphere-only version of the UK Meteorological Office Unified Model (HadGAM1) show that using the AMIP2-SST produces a dry bias in rainfall over the Maritime Continent (Figure 4a), as mentioned earlier. A $1^{\circ} \mathrm{C}$ rise in
SST just within Indonesia (Figure 4b) results in a significant change in precipitation distribution in a direction that begins to correct the model dry bias. Further, applying this regional SST anomaly also has remote impacts across the whole Indo-Pacific region. $\mathrm{A} 1^{\circ} \mathrm{C}$ anomaly applied over Indonesia results in a significant decrease in precipitation over the western Pacific and western Indian Oceans, areas which without the forcing

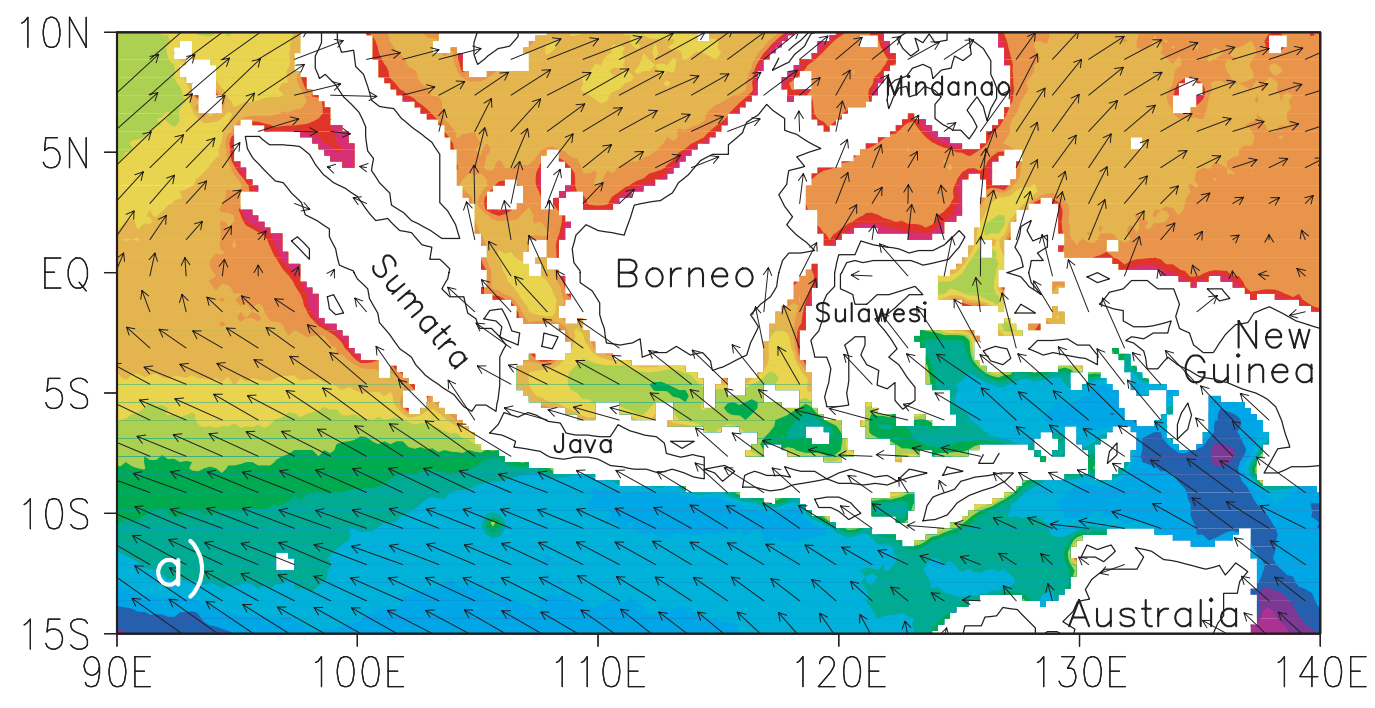

Figure 3. Monthly mean TRMM sea surface temperature $\left({ }^{\circ} \mathrm{C}\right)$ superimposed with Quick Scatterometer (QuikSCAT) wind $(\mathrm{m} / \mathrm{s})$ in (a) August and (b) February. Data are averaged from December 1997 to June 2004 and from July 1999 to January 2005 , respectively. Here, the monsoon influence is evident. The sea surface temperature tends to warm up in the downstream direction of the wind and cool down in the upstream direction.

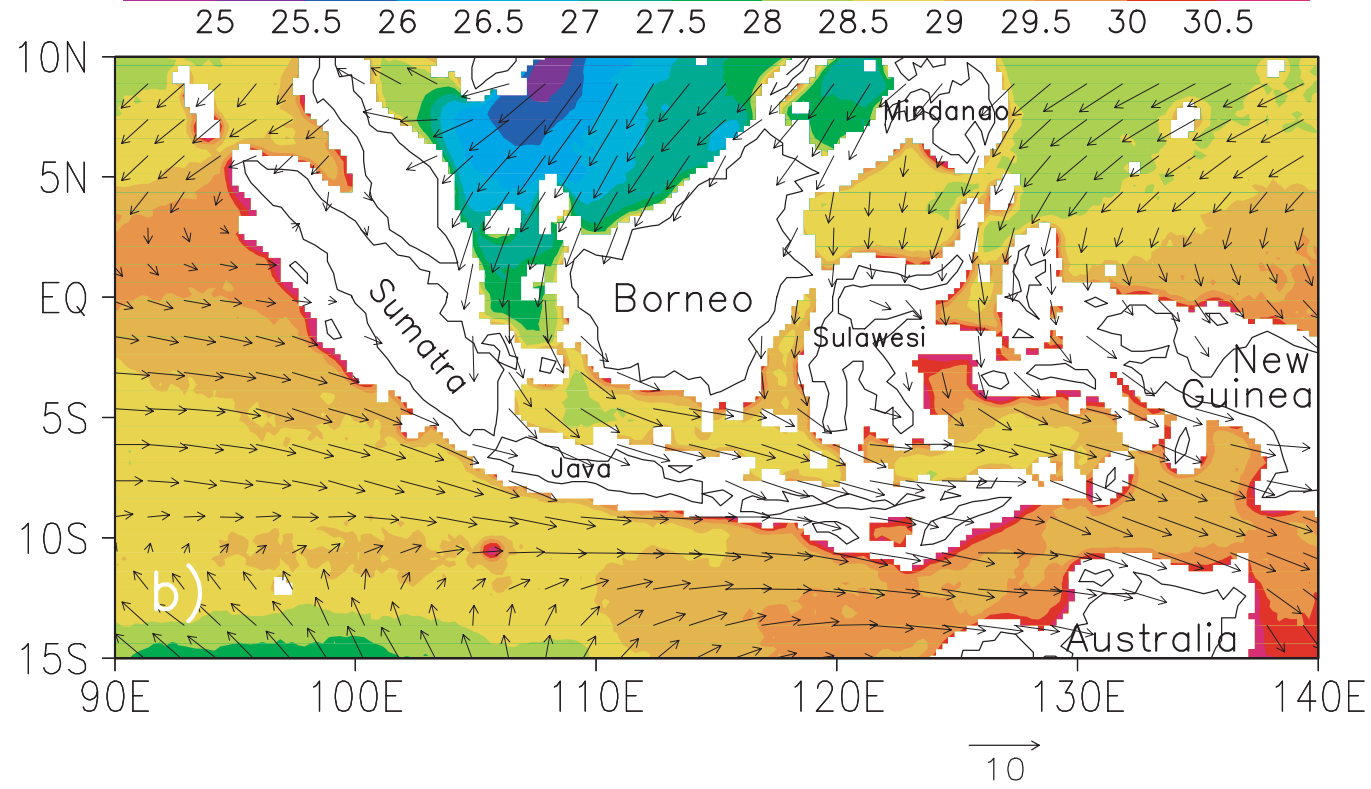


show a wet bias (Figure 4a). Applying similar SST anomalies elsewhere in the Indo-Pacific region does not produce remote responses. These results reveal the significance of SST in the Maritime Continent to the whole of the tropics.

A similar experiment with a $0.5^{\circ} \mathrm{C}$ anomaly (Figure 4c) shows that the convective response over the region does not appear to be linear. Applying a $0.5^{\circ} \mathrm{C}$ anomaly produces precipitation increas- es up to $6 \mathrm{~mm} /$ day compared to increases up to $18 \mathrm{~mm} /$ day with a $1^{\circ} \mathrm{C}$ anomaly. Additionally, the $0.5^{\circ} \mathrm{C}$ anomaly produces much weaker remote effects.

These results show that the atmosphere over the Maritime Continent is highly sensitive to changes in SST. It is clear that the SSTs must be accurately prescribed in models in order to correctly reproduce the observed atmospheric response. In the following sections, we review some of the oceanic mechanisms that ultimately will have to be taken into account in regional climate modeling.

\section{TIDAL MIXING AND UPWELLING}

The Indonesian region has the strongest tidal currents of the tropical ocean (Robertson and Ffield, this issue). These currents generate intense ocean mixing, which influences SST in numerous

(a) control-CMAP observational data

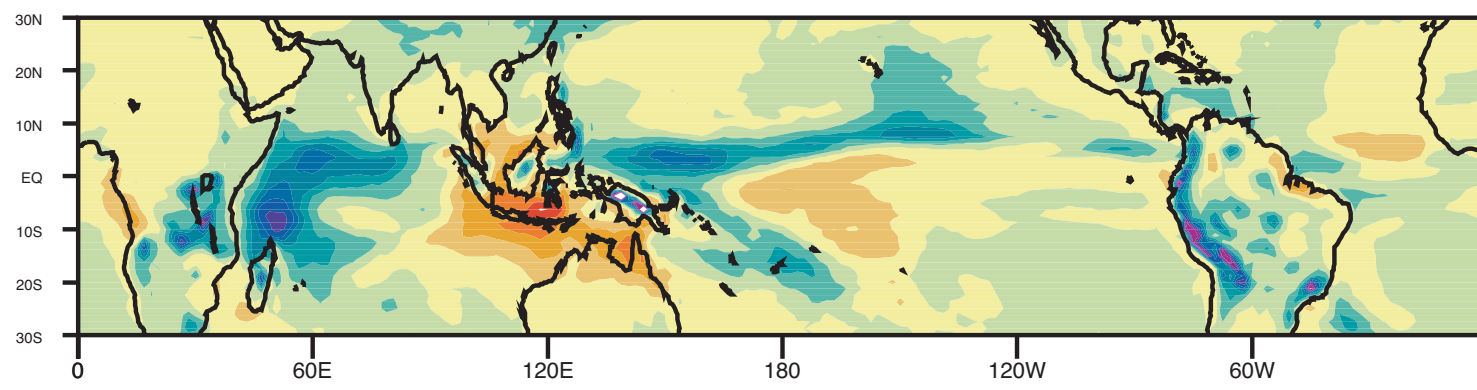

(b) +1K Maritime Continent SST anomaly-control

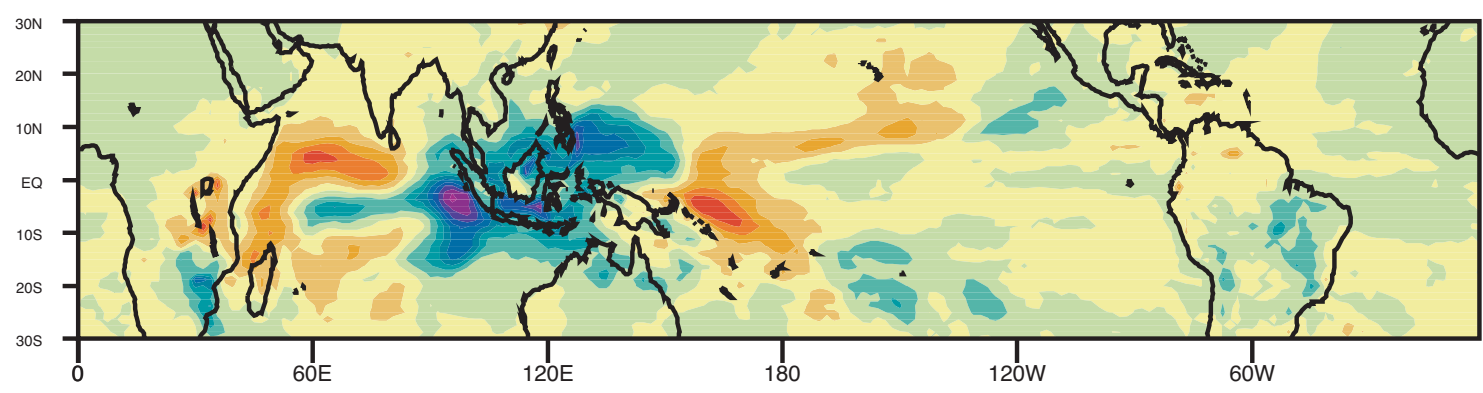

(c) +0.5K Maritime Continent SST anomaly-control

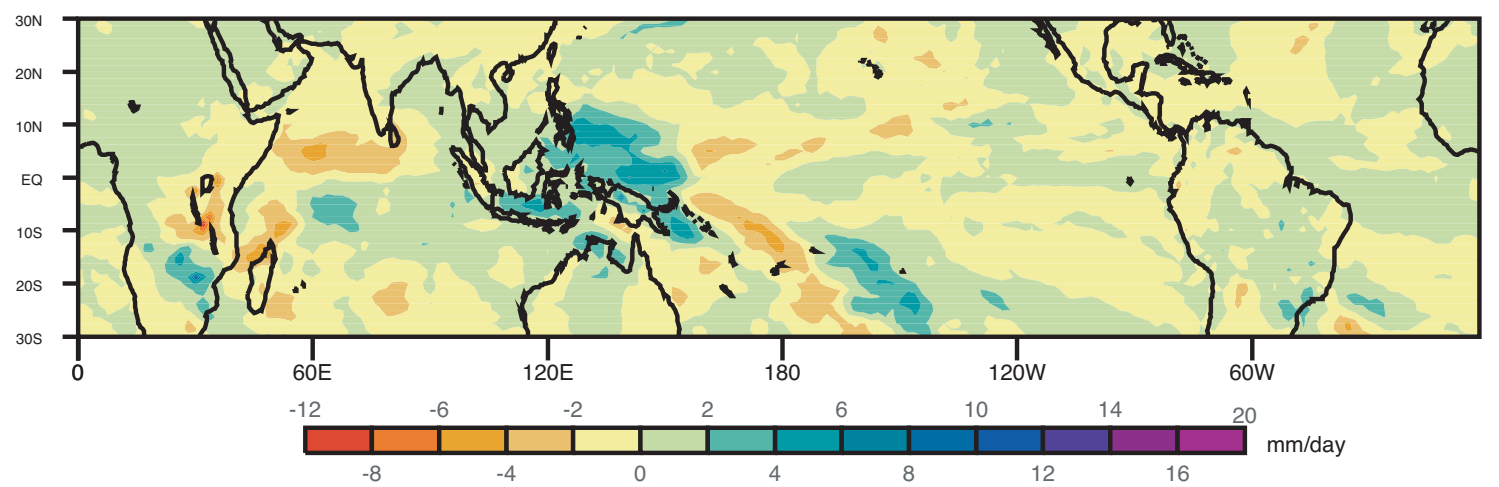

Figure 4. Precipitation results from the atmosphereonly version of the UKMO UM (UK Meteorological Office Unified Model), HadGAM1 (Hadley Centre climate model). (a) The error in the model when compared against precipitation data from the Climate Prediction Centre's (CPC) Merged Analysis of Precipitation (CMAP) (Xie and Arkin, 1996). (b) The change from the control model when a $1^{\circ} \mathrm{C}$ anomaly is applied to the Maritime Continent region $\left(90^{\circ} \mathrm{E}-160^{\circ} \mathrm{E}, 17.5^{\circ} \mathrm{S}-15^{\circ} \mathrm{N}\right)$. (c) The change from the control model when a $0.5^{\circ} \mathrm{C}$ anomaly is applied to the Maritime Continent region. The results reveal the significance of sea surface temperature in the Maritime Continent to the precipitation of the whole tropics. 
channels and basins of the archipelago

(Ffield and Robertson, this issue). Tidalmixing-induced changes in SST modulate ocean-atmosphere heat exchange as well as convective rainfall. Recent studies have found that the strong fortnightly component of tides correlates with a fortnightly change in rainfall over the Indonesian archipelago: strong tides lead to a cooler ocean surface and reduced rainfall (e.g., Ffield and Gordon, 1996). Other links of tides to regional climate are being investigated.

The seasonally reversing monsoon also creates upwelling. Wyrtki (1962) first showed the location of upwelling in the region, based on early in situ observations. The TMI (Wentz et al., 2000) provides a detailed picture of seasonal upwelling in the region (Figure 3). The southern coasts of Java and Flores Island, the southern coast of Irian Jaya, and the eastern Banda Sea in particular are areas of extensive upwelling.

The impact of mixing and upwelling extends beyond SST. Satellite ocean color
(Figure 5) shows high values of chlorophyll concentration in the upwelling areas as well as within $200-500 \mathrm{~km}$ of the coast off most Indonesian islands, implying that strong tidal mixing and seasonal upwelling also influence the nutrient concentrations, which further influence fishery and biological productivity in the region (Hendiarti et al., this issue).

\section{REMOTE INFLUENCE FROM THE PACIFIC}

The Indonesian throughflow (ITF) (Gordon, 1986; Godfrey, 1996; Lee et al., 2002; Gordon, this issue) is influential in regulating regional SST. Without the constant supply of warm ITF water and a deep thermocline transmitted from the western equatorial Pacific, the Indonesian region, as well as the entire southeastern tropical Indian Ocean, would be as dry and cold as the west coast of South America (Wajsowicz and Schneider, 2001). In the Makassar Strait, for example, recent mooring observations (Ffield et al., 2000) showed the correlation between ITF strength, depth of thermocline, and SST. Seasonally, the maximum impact of ITF on SST usually comes in late northern summer when the pressure gradient between the Pacific and the Indian Ocean is greatest (Wyrtki, 1987; Meyers et al., 1995).

Another important pathway is water entering the Java Sea from the South China Sea through Karimata Strait $(\mathrm{Qu}$ et al., 2004). On the seasonal time scale, this flow has a maximum impact on SST in boreal winter when the Luzon Strait Transport is strongest and the bifurcation of the North Equatorial Current (NEC) occurs at its northernmost position $(\mathrm{Qu}$ and Lukas, 2003). In response, the buoyant, low-salinity South China Sea surface water then flows into the southern Makassar Strait, creating a northward pressure gradient in the surface layer of the strait (Gordon et al., 2003), inhibiting the ITF's warming effect.

SST variability at a broad range of time scales is a consequence of the unique position of Indonesia at the con-

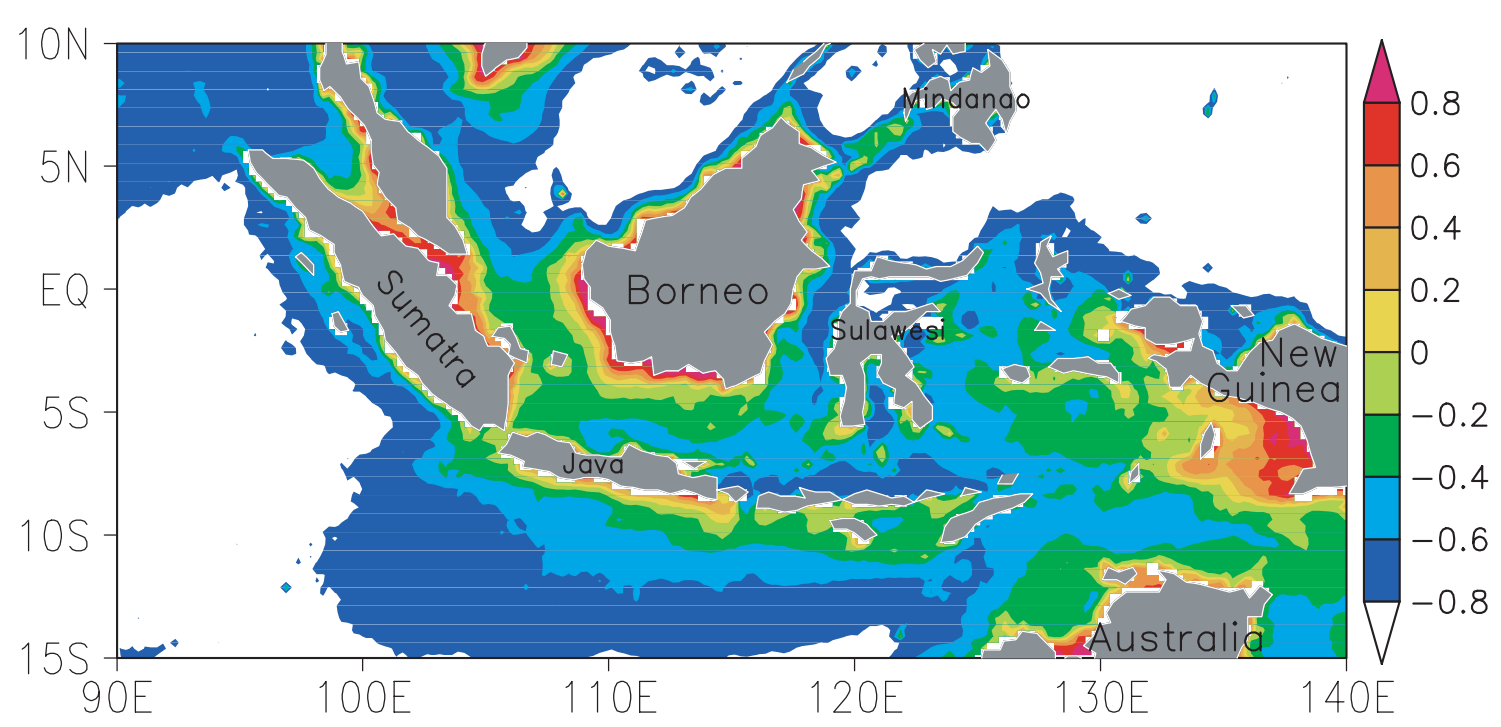

Figure 5. Average July to September chlorophyll concentration $\left(\log _{10} \mathrm{mg} /\right.$ $\mathrm{m}^{3}$ ) 1997-2003, from Seaviewing Wide Field-of-view Sensor (SeaWiFs). The high chlorophyll concentration during this season offers evidence for the existence of upwelling within $200-500 \mathrm{~km}$ of the coast, despite its indistinct signature in the sea surface temperature. 
fluence of the Pacific and Indian equatorial and coastal waveguides (Clarke and Liu, 1994). Thus, the depth of the thermocline and SST in the region can be influenced by remote equatorial winds in the Pacific and Indian Oceans. This mechanism allows the El Niño-Southern Oscillation (ENSO) to influence regional SST (Meyers, 1996; Potemra, 2001; Wijffels and Meyers, 2004). The cold SST anomalies in Makassar Strait during the peak of 1997/98 El Niño (Susanto and
Gordon, 2005) are well captured by the satellite's TMI measurements (Figure 6a). Moreover, Ffield et al. (2000) found that the Makassar thermocline temperature is highly correlated $(\mathrm{r}=0.77)$ to the Southern Oscillation Index (SOI).

\section{REMOTE INFLUENCE FROM THE INDIAN OCEAN}

SST in the region is also influenced by variations in wind over the equatorial Indian Ocean, transmitted in the ther- mocline (Potemra, 2001; Wijffels and Meyers, 2004). Variations in zonal winds in the central Indian Ocean generate equatorial Kelvin waves, which propagate eastward along the equatorial waveguide. Upon approaching the Indonesian coast, the reflected equatorial Kelvin waves push the thermocline down along the Sumatra-Java-Nusa coast, changing the mixed layer depth and hence the response to surface fluxes or upwelling and mixing. A strong manifestation of

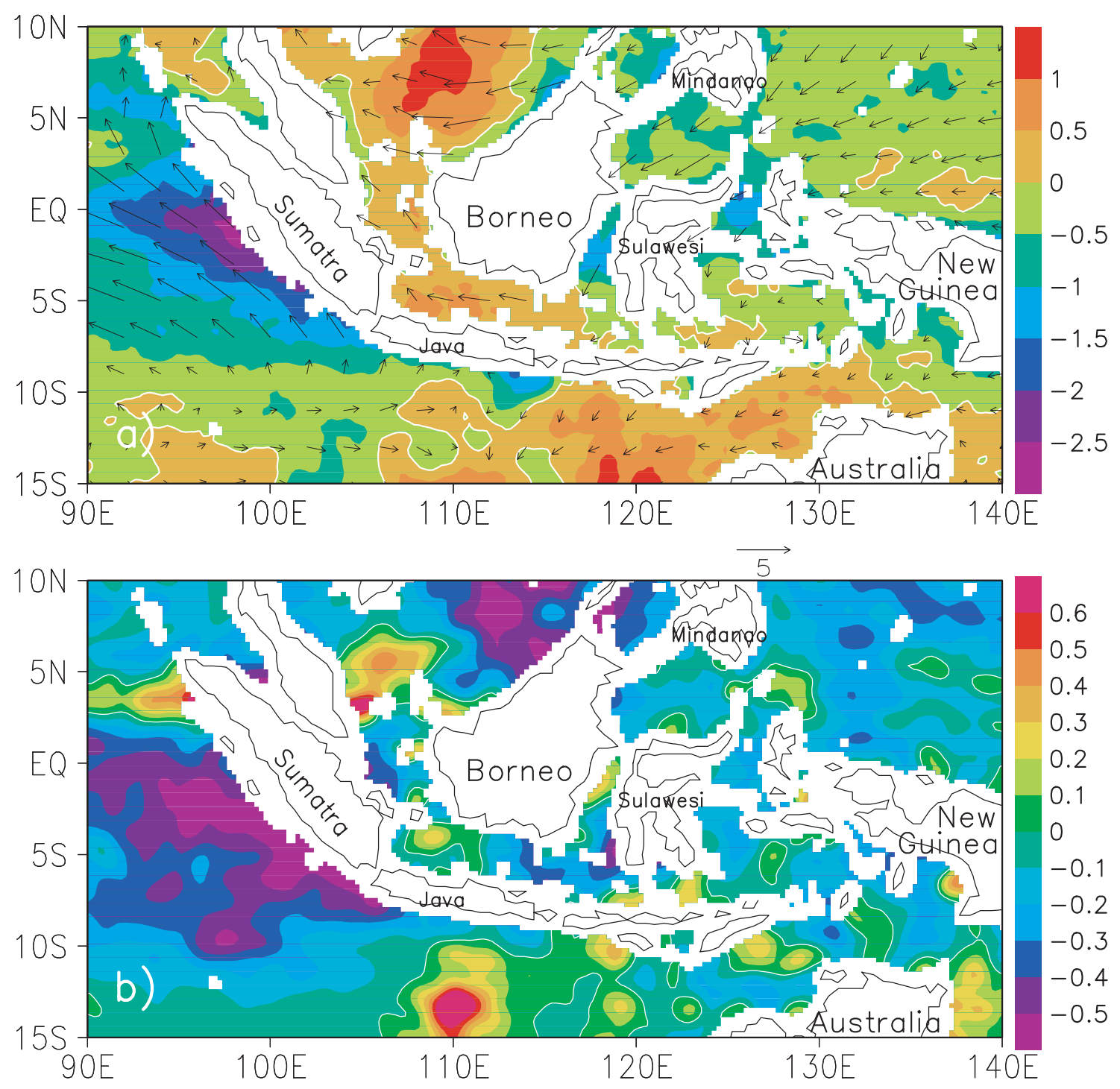

Figure 6. (a) Anomalous TRMM sea surface temperature $\left({ }^{\circ} \mathrm{C}\right)$ superimposed with Special Sensor Microwave Imager (SSM/I) wind $(\mathrm{m} / \mathrm{s})$ and $(\mathrm{b})$ anomalous TRMM precipitation $\left(10^{3}\right.$ $\mathrm{mm} / \mathrm{mon}$ ) in December 1997. The cold sea surface temperature and negative precipitation anomalies near the coast of Indonesia were well captured, indicative of the occurrence of an Indian Ocean Dipole event (Saji et al., 1999). 
this process, occurring twice a year during monsoon transitions, is known as the Wyrtki Jets (Wyrtki, 1973).

Recently, as a result of the occurrence of extreme events in 1994 and 1997, con- over the Indian subcontinent (Annamalai and Slingo, 2001). A positive IOD event is usually accompanied by heavy rainfall in eastern Africa and droughts in Indonesia (Figure 6b).

\section{...it is important to accurately prescribe SSTS}

in the Maritime Continent in climate models

so that they will correctly reproduce the

\section{response in the atmosphere, and hence better predict future climatic conditions.}

siderable attention has been focused on an ocean-atmosphere coupled phenomenon known as the Indian Ocean Dipole (IOD) mode (Saji et al., 1999), which is also known as the Indian Ocean Zonal (IOZ) mode (Webster et al., 1999). The positive phase of IOD is characterized by an east-west dipole pattern in SST anomalies spanning the Indian Ocean basin. Like the Pacific ENSO, the evolution of IOD is strongly locked to the annual cycle. In its active years, cold SST anomalies off Java and Sumatra typically develop in June to August and peak in September to October (Figure 6a), while warm SST anomalies in the western Indian Ocean occur later. The SST anomalies are found to be closely associated with changes in surface winds. Equatorial winds reverse direction from westerlies to easterlies during the peak phase of IOD when SST is cold in the east and warm in the west (Figure 6a). Changes in surface winds are associated with a basin-wide anomalous Walker circulation (Yamagata et al., 2002), as well as anomalous local Hadley cell and monsoons

\section{SEASONAL UPWELLING OFF JAVA AND SUMATRA}

SST variability off Java and Sumatra is a key component of IOD and is strongly coupled to the seasonal cycle. In the usual upwelling season (June to August), we do not see a SST depression of any more than a few tenths of a degree centigrade off Java and Sumatra (Figure 3a), despite the upwelling-favorable southeast monsoon. This is highly unusual compared to other upwelling regions off North and South America and Africa. The high chlorophyll concentration at this season offers evidence for the existence of upwelling within 200-500 km of the coast (Figure 5). As wind blows from the southeast, water is drawn from below and carried offshore in the surface layer, inducing widespread upwelling along the coast of Indonesia (Wyrtki, 1962; Susanto et al., 2001). The upward movement brings high-nutrient water from the thermocline into the euphotic layer where phytoplankton develop under increasing light penetration. As part of the southwestward Ekman current, high- chlorophyll-concentration water permeates from the coast to about $98^{\circ} \mathrm{E}$. But, why does the upwelling not appear in the pattern of SST, as it does in other eastern boundary regions? A detailed answer to this question illustrates many of the difficulties that must be faced in developing an adequate simulation of regional SST in a climate model.

This question was first raised by Wyrtki (1962), but has received little attention until recent studies of Quadfasel and Cresswell (1992), Qu et al. (1994), and Du et al. (2005). The small SST depression off Java and Sumatra results from internal and external factors. The region is unique, partly because of the existence of the ITF. The ITF transfers a large amount of warm, fresh water from the Pacific to the Indian Ocean, and affects both the regional circulation and thermal structure (Qu and Meyers, 2005). A quantitative analysis of the upper-layer heat budget (Qu et al., 1994), based on results from a coarse-resolution $\left(0.5^{\circ}\right.$ $\left.\mathrm{x} 0.5^{\circ}\right) \mathrm{GCM}$, indicates that seasonal warming advection by the ITF cancels the cooling by upwelling near the coast of Java. This cancellation effect explains why upwelling doesn't appear in the pattern of SST. The emergence of higherresolution $\left(\leq 0.1^{\circ}\right)$ GCMs allows a fresh look at this problem.

Despite some differences in quantitative detail, a recent study (Du et al., 2005) using results from a high-resolution GCM confirms Qu et al.'s (1994) interpretation for the small SST depression south of Java. In addition to the ITF, Du et al. (2005) found that the barrier layer, representing an intermediate layer that separates the base of the mixed layer from the top of the thermocline (Lukas 
and Lindstrom, 1991), is another unique factor influencing the SST variability in the region. To the west of Sumatra, in particular, large rainfall and runoff persist year round. The enhanced surface stratification sustains a shallow mixed layer, but a thick barrier layer (Sprintall and Tomczak, 1992; Masson et al., 2002; $\mathrm{Qu}$ and Meyers, in press). From boreal summer to fall, the mixed layer is relatively shallow. Because of the topographically oriented rainfall and runoff, contours of mixed-layer depth tend to follow the coastline all the way from south Java to west Sumatra (Figure 7a). The southwestward Ekman current forced by southeast monsoon creates a crossshelf pressure gradient that generates the northwestward South Java Current (SJC) (Quadfasel and Cresswell, 1992). The SJC advects low-salinity surface water stemming from the large P-E (precipitation minus evaporation) $(\sim 10 \mathrm{~mm} /$ day $)$ to the equator and horizontally homogenizes the salinity distribution along the coast (e.g., Masson et al., 2002). Coastal upwelling, however, is shallow $(<50 \mathrm{~m})$ and has little effect on the deeper thermocline. The presence of a thick barrier layer (Figure 7b) impedes cold thermocline water from entering the mixed layer, and this explains why the depression of SST off Sumatra is small compared with other eastern boundary upwelling regions like that west of Peru in the eastern Pacific (Du et al., 2005).

Analysis of the seasonal heat budget sets the background for further study of interannual variability in the region off Java and Sumatra. As noted above, ITF variability is primarily controlled by the winds over the Pacific Ocean, while depth of the thermocline off Java and
Sumatra is controlled primarily by the winds over the equatorial Indian Ocean. The Pacific and Indian Ocean wind fields are not tightly coupled and they display substantially different time scales of variability (Wijffels and Meyers, 2004).
A number of recent ocean GCM experiments show that the barrier-layer thickness, rainfall, and SST anomalies are tightly correlated in the region near Sumatra on interannual time scales (Murtugudde and Busalacchi, 1999; Masson
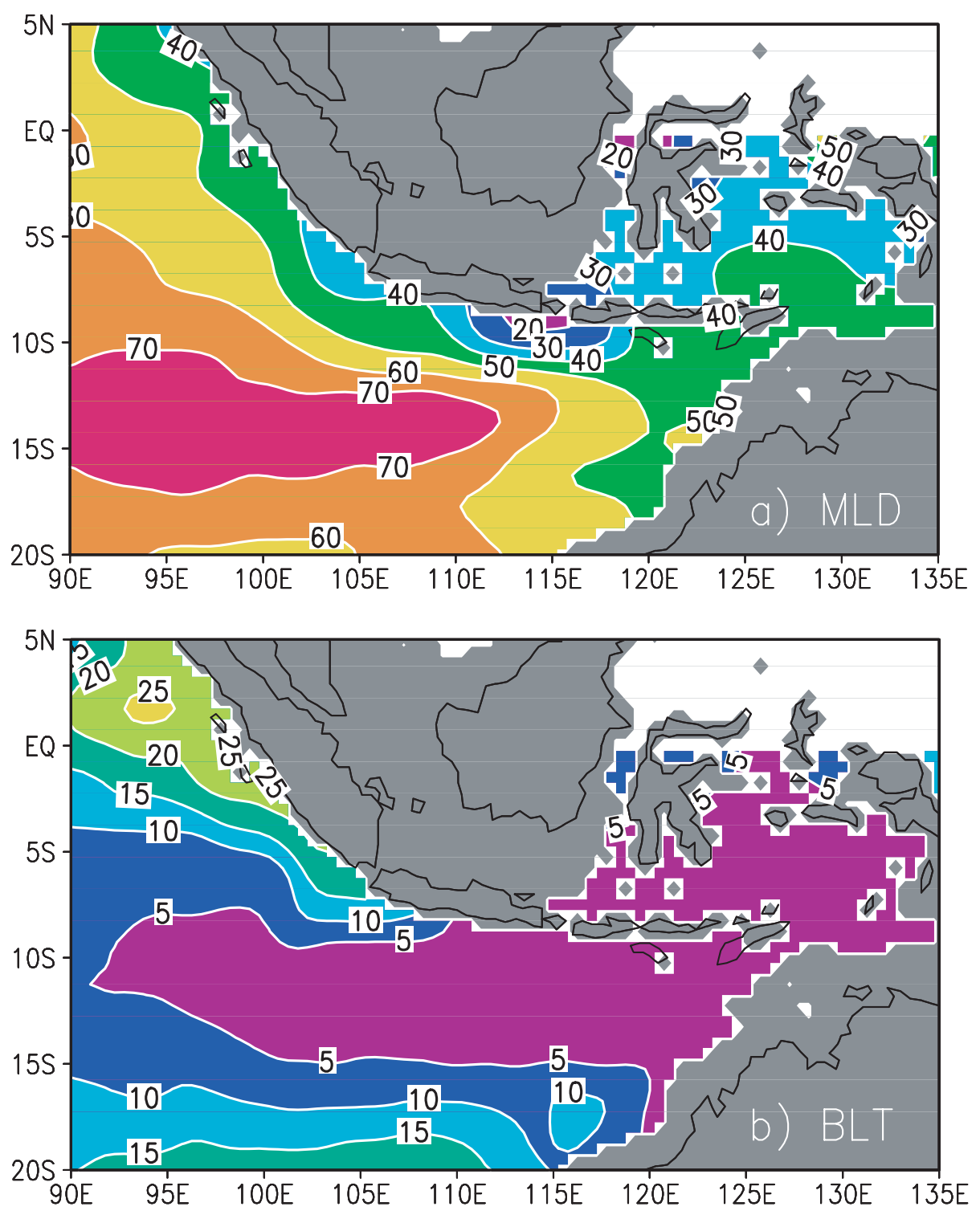

Figure 7. (a) Monthly mean mixed layer depth and (b) barrier layer thickness ( $\mathrm{m}$ ) from July to September (adapted from Qu and Meyers, in press). The existence of a thick (>20 m) barrier layer explains why the sea surface temperature depression off Java and Sumatra is small compared with other eastern boundary upwelling regions like that west of Peru in the eastern Pacific (Du et al., 2005). 
et al., 2004). In terms of the correlation between SST and thermocline depth anomalies, this region is important for the growth of IOD in the Indian Ocean.

\section{DISCUSSION}

The Indonesian region SST is of major importance to atmospheric state, not only over the region itself, but globally. Convection, which is dependent on the SST, is the dominant atmospheric process over the region. Convective activity drives atmospheric circulation and contributes to global energy and moisture budgets. Therefore, it is important to accurately prescribe SSTs in the Maritime Continent in climate models so that they will correctly reproduce the response in the atmosphere, and hence better predict future climatic conditions.

We have provided a general description of the SST variability in the Indonesian region. As the SST variability in the region has a great impact on regional climate, environment, economy, and biological productivity, we hope such a description will be useful for the design and analysis of future observations. In addition, we have surveyed recent studies to address the questions of whether and how oceanic processes play a role in generating the observed SST anomalies of the region.

The SST distribution in the region is complex, varying considerably in both time and space. This complexity makes it difficult to understand the processes that control the SST variability. Different processes are dominant on different time scales in different parts of the region. Within the Indonesian archipelago, local monsoon and tidal mixing are important, and probably explain a significant part of the mean seasonal SST cycle. These processes, however, become less important on longer time scales; the interannual SST variability can be largely understood in terms of Kelvin and Rossby waves generated by remote zonal winds along the Indian and Pacific equators. The volume transport of ITF is another important factor influencing water temperature in the region. This influence is primarily in the depths of the thermocline, but it influences SST in regions of upwelling and strong vertical (tidal) mixing.

The directly monsoon-driven circulation in the surface layer of Java Sea contributes to the seasonal ITF variability as well as SST in Makassar Strait. This result implies an important oceanic connection between the tropical Pacific Ocean and the Indonesian seas. As a source and sink of the Java Sea's surface flow, the South China Sea is believed to play an important role in the connection. On interannual time scales, the inflow of cold, relatively fresh South China Sea water through Karimata Strait has its maximum strength around the mature phase of El Niño (Qu et al., 2004). A natural question is how this inflow contributes to the ITF and regional SST. This question needs to be addressed by future studies.

The largest SST variability in the Indonesian region occurs in the coastal region off Java and Sumatra. Despite the prevailing southeasterly winds in boreal summer, the upwelling signature is present in the SST pattern only during IOD events. In normal years, the SST depression across the Java/Sumatra coast is small, presumably as a result of warming advection by ITF and the formation of a thick barrier layer. We expect that the delicate balances of advection, upwelling/entrainment, and barrier-layer formation will not always be maintained on interannual time scales. This occasional imbalance leads to substantially different realizations of the seasonal heat budget, thus allowing for strong upwelling signature in the sea surface in some particular events. No observational evidence is available to support a heat-budget analysis of this speculation. The promise of recent highresolution GCM results warrants a more extensive exploration to determine factors that initiate the cold SST anomalies off Java/Sumatra, as well as modulate their evolution in the IOD events.

Finally, we note that the Indonesian region has suffered, and will continue to suffer, from scarcity of data and in particular, of regionally consistent data. Although weather-station-based SST observations from Indonesia and nearby countries have been analyzed individually, there have been few attempts to collect these data sets and quantify the spatial and temporal variability of SST over the entire region. Recent satellite observations provide for the first time an overall view of SST variability in the region, but the characteristics have not been systematically compared with those derived from the much longer and locally dense weather-station-based data sets. Retrieving data from historical archives in Indonesia and nearby countries is probably the most cost-effective way of obtaining long-term SST observations in the region.

\section{ACKNOWLEDGEMENTS}

The National Aeronautics and Space Administration supported this research through grant NAG5-12756. The Japan Marine Science and Technology Center also supported TQ through its sponsorship of the International Pacific Research 
Center (IPRC), and GM by the CSIRO Wealth from Oceans Flagship Program. The authors are grateful to A.L. Gordon for his kind invitation to make this contribution, and to E.J. Lindstrom and an anonymous reviewer for valuable comments on the earlier version of this manuscript. IPRC contribution number IPRC-348, and School of Ocean and Earth Science and Technology contribution number 6655. 可

\section{REFERENCES}

Annamalai, H., and J.M. Slingo. 2001. Active/Break Cycles: Diagnosis of the intraseasonal variability of the Asian summer monsoon. Climate Dynamics 18:85-102.

Ashok, K., Z. Guan, and T. Yamagata. 2001. Impact of the Indian Ocean Dipole on the relationship between Indian Ocean monsoon rainfall and ENSO. Geophysical Research Letters 28:4,499-4,502.

Bray, N.A., S. Hautala, J. Chong, and J. Pariwono. 1996. Large-scale sea level, thermocline, and wind variations in the Indonesian throughflow region. Journal of Geophysical Research 101:12,23912,254 .

Clarke, A.J., and X. Liu. 1994. Interannual sea level in the northern and eastern Indian Ocean. Journal of Physical Oceanography 24:1,224-1,235.

Du, Y., T. Qu, G. Meyers, Y. Masumoto, and H. Sasaki. 2005. Seasonal heat budget in the mixed layer of the southeastern tropical Indian Ocean in a high-resolution global general circulation model. Journal of Geophysical Research 110:C04012, doi:10.1029/2004JC002845.

Ffield, A, and A.L. Gordon. 1996. Tidal mixing signatures in the Indonesian Seas. Journal of Physical Oceanography 26:1,924-1,937.

Ffield, A., K. Vranes, A.L. Gordon, and D. Susanto. 2000. Temperature variability within Makassar Strait. Geophysical Research Letters 27:237-240.

Gates, W.L. 1992. AMIP: The Atmospheric Model Intercomparison Project. Bulletin of the American Meteorological Society 73:1,962-1,970.

Godfrey, J.S. 1996. The effect of the Indonesian throughflow on ocean circulation and heat exchange with the atmosphere: A review. Journal of Geophysical Research 101:12,217-12,237.

Gordon, A.L. 1986. Interocean exchange of thermocline water. Journal of Geophysical Research 91:5,037-5,046.

Gordon, A.L., R.D. Susanto, and K. Vranes. 2003. Cool Indonesian throughflow as a consequence of restricted surface layer flow. Nature 425:824-828.

Kummerow, C., W. Barnes, T. Kozu, J. Shiue, and J. Simpson. 1998. The Tropical Rainfall Measuring
Mission (TRMM) sensor package. Journal of Atmospheric and Oceanic Technology 15:809-817.

Lee, T., I. Fukumori, D. Menemenlis, D. Zhang, and L. Fu. 2002. Effects of the Indonesian throughflow on the Pacific and Indian Oceans. Journal of Physical Oceanography 32:1,404-1,429.

Lukas, R., and E. Lindstrom. 1991. The mixed layer of the western equatorial Pacific Ocean. Journal of Geophysical Research 96(Suppl.):3,343-3,357.

Masson, S., J.P. Boulanger, C. Menkes, P. Delecluse, and T. Yamagata. 2004. Impact of salinity on the 1997 Indian Ocean dipole event in a numerical experiment. Journal of Geophysical Research 109: C02002, doi: 10.1029/2003JC001807.

Masson, S., P. Delecluse, J.P. Boulanger, and C. Menkes. 2002. A model study of the seasonal variability and formation mechanisms of the barrier layer in the eastern equatorial Indian Ocean. Journal of Geophysical Research 107:8017, doi:10.1029/ 2001JC000832.

McBride, J.L., M.R. Haylock, and N. Nichols. 2003. Relationships between the maritime continent heat source and the El Niño-Southern Oscillation phenomenon. Journal of Climate 16:2,905-2,914.

Meyers, G. 1996. Variation of Indonesian throughflow and the El Niño-Southern Oscillation. Journal of Geophysical Research 101:12,255-12,263.

Meyers, G., R.J. Bailey, and A.P. Worby. 1995. Geostrophic transport of Indonesian throughflow. Deep-Sea Research Part I 42:1,163-1,174.

Miller, M.J., A.C.M. Beljaars, and T.N. Palmer. 1992. The sensitivity of the ECMWF model to the parameterization of evaporation from the tropical oceans. Journal of Climate 5:418-434.

Murtugudde, R., and A.J. Busalacchi. 1999. Interannual variability of the dynamics and thermodynamics of the tropical Indian Ocean. Journal of Climate 12:2,300-2,326.

Neale, R.B., and J.M. Slingo. 2003. The Maritime Continent and its role in the global climate: A GCM study. Journal of Climate 16:834-848.

Potemra, J.T. 2001. Contribution of equatorial Pacific winds to southern tropical Indian Ocean Rossby waves. Journal of Geophysical Research 106:2,407-2,422.

$\mathrm{Qu}, \mathrm{T}$., and G. Meyers. In press. Seasonal variation of the barrier layer in the southeastern tropical Indian Ocean. Journal of Geophysical Research.

Qu, T., and G. Meyers. 2005. Seasonal characteristics of circulation in the southeastern tropical Indian Ocean. Journal of Physical Oceanography 35:255-267.

Qu, T., and R. Lukas. 2003. On the bifurcation of the North Equatorial Current in the Pacific. Journal of Physical Oceanography 33:5-18.

Qu, T., Y.Y. Kim, M. Yaremchuk, T. Tozuka, A. Ishida, and T. Yamagata. 2004. Can Luzon Strait Transport play a role in conveying the impact of ENSO to the South China Sea? Journal of Climate 17:3,644-3,657.

Qu, T., G. Meyers, J.S. Godfrey, and D. Hu. 1994.
Ocean dynamics in the region between Australia and Indonesia and its influence on the variation of sea surface temperature in a global general circulation model. Journal of Geophysical Research 99:18,433-18,445.

Quadfasel, D., and. G.R. Cresswell. 1992. A note on the seasonal variability of the South Java Current. Journal of Geophysical Research 97:3,685-3,688.

Saji, N.H., B.N. Goswami, P.N. Vinayachandran, and T. Yamagata. 1999. A dipole mode in the tropical Indian Ocean. Nature 401:360-363.

Sprintall, J., and M. Tomczak. 1992. Evidence of the barrier layer in the surface layer of the tropics. Journal of Geophysical Research 97:7,305-7,316.

Susanto, R.D., and A.L. Gordon. 2005. Velocity and transport of the Makassar Strait throughflow. Journal of Geophysical Research 110:C01005, doi:10.1029/2004JC002425.

Susanto, R.D., A.L. Gordon, and Q. Zheng. 2001. Upwelling along the coasts of Java and Sumatra and its relation to ENSO. Geophysical Research Letters 28:1,599-1,602.

Wajsowicz, R.C., and E.K. Schneider. 2001. The Indonesian throughflow's effect on global climate determined from the COLA coupled climate system. Journal of Climate 14:3,029-3,042.

Webster, P.J., A.M. More, J.P. Loschnigg, and R.R. Leban. 1999. Coupled ocean-atmosphere dynamics in the Indian Ocean during 1997-98. Nature 401:356-360.

Wentz, F.J., C. Gentemann, D. Smith, and. D. Chelton. 2000. Satellite measurements of sea surface temperature through clouds. Science 288:847-850.

Wijffels, S., and G. Meyers. 2004. An intersection of oceanic waveguides: variability in the Indonesian throughflow region. Journal of Physical Oceanography 34:1,232-1,253.

Wyrtki, K. 1987. Indonesian throughflow and the associated pressure gradient. Journal of Geophysical Research 92:12,941-12,946.

Wyrtki, K. 1973. An equatorial jet in the Indian Ocean. Science 181:262-264.

Wyrtki, K. 1962. The upwelling in the region between Java and Australia during the south-east monsoon. Australian Journal of Marine and Freshwater Research 13:217-225.

Wyrtki, K. 1961. Physical oceanography of Southeast Asian waters. Naga Report 2. Scripps Institution of Oceanography, La Jolla, CA, 195 pp.

Xie, P.P., and P.A. Arkin. 1996. Analyses of global monthly precipitation using gauge observations, satellite estimates and numerical model predictions. Journal of Climate 9:840-858.

Yamagata, T., S.K. Behera, S.A. Rao, Z. Guan, K. Ashok, and H.N. Saji. 2002. The Indian Ocean dipole: a physical entity. CLIVAR Exchange 24:15-18, 20-22.

Yang, G.Y., and J.M. Slingo. 2001. The diurnal cycle in the tropics. Monthly Weather Review 129:784-801. 